ISSN: 0331-4111

Volume 17, No. 1, June 2019

Pages 1-16

DOI: $10.36108 / \mathrm{NJSA} / 9102 / 71(0110)$

\title{
Plucking the Flower Just too Early: Some Community Perspectives on Age at Marriage among Adolescent Girls in a Nigerian State
}

\author{
Jimoh Amzat \\ Department of Sociology \\ Usmanu Danfodiyo University \\ Sokoto, Nigeria
}

\begin{abstract}
In northern Nigeria, there are cultural and religious pressures on girls to marry early. Up to 43\% of girls in Nigeria are married before 18, rising as high as $87 \%$ in the northwest. The study, using a mixed method approach, examines behaviours of community members towards adolescent girls' time of marriage with perspectives from adolescent girls, faith leaders, and community members. The study found that the practice of early marriage exists in the areas studied: $35 \%$ of survey respondents had one or more daughters married before the age of 18, although most community members believed that a girl should be married when she is "mature". Only 9.6\% of survey respondents noted that they would never marry off an underage daughter. As major stakeholders in multi-component interventions, the study identifies the crucial roles of faith leaders in efforts to reduce the practice of early marriage in northern Nigeria.
\end{abstract}

Keywords: Early marriage, faith leaders, northern Nigeria

\section{Introduction}

In many parts of the world, parents encourage the marriage of their daughters while they are still children in hopes that the marriage will benefit them both financially and socially. Unfortunately, child marriage is a violation of human rights, compromising the development of girls and often resulting in early and risky pregnancy and social isolation, with little education and poor vocational training reinforcing the gendered nature of poverty (NBS, UNICEF and UNFPA, 2013). Adolescent Girls (AGs), understood in this research as those girls in the state of development between puberty and maturity (12 to 18 years old), have very limited choices and opportunities to reach their full potential in Northern Nigeria (Christian Aid, 2017). Cultural and religious socialization has resulted in girls feeling isolated and powerless and therefore conforming to cultural pressures. Many face both systematic and structural marginalization (NPC and ICF Macro, 2009). Up to $43 \%$ of girls in Nigeria are married before 18 , with child marriage prevalence going as high as $87 \%$ in the northwest (AfriDevInfo, 2016).

Education is a reliable indicator of whether a girl will marry as a child. According to Nigerian demographic survey, $82 \%$ of women with no education were married before 18 , as opposed to $13 \%$ of women who had at least finished 
secondary education (NPC and ICF Macro, 2009). Nearly two-thirds of women in the north-west and north-east regions have no education, compared to less than $15 \%$ in the South (NPC and ICF Macro, 2009). Adolescent Girls' education and empowerment are shown to be vital in lifting families out of poverty with development outcomes for individual AG benefiting their families, communities, and nations (NPC and ICF Macro, 2009). It is generally assumed that economic empowerment will not only increase their income, but it will also have ripple effects for their families, communities, and countries (NPC and ICF Macro, 2009).

Child marriage is a form of arranged/forced and non-consensual union. UNFPA (2012) observed that in the least-developed countries, the prevalence of child marriage is very high, as almost $50 \%$ of girls or more will marry before the age of 18. Girls as low as ten years old might be forced into marriage. While Niger and Chad have prevalence rates of over $70 \%$ (UNFPA, 2012), the number of incidents in Nigeria is higher because of its large population (estimated up to 180 million people). In Nigeria, there are variations of prevailing rates across the States; the North bears the brunt of the burden of early marriage. The highest rates of child marriage in Nigeria are in Jigawa and Bauchi with $87 \%$ and $84 \%$ respectively (AfriDevInfo, 2016). Kaduna is a northern state with the prevalence of $56 \%$, which is also above the national average of $39 \%$ in Nigeria according to the UNFPA (2012) or $43 \%$ according to AfriDevInfo (2016).

It is estimated that nearly 80 percent of the world population are affiliated to one religion or the other with a majority belonging to an organized religion such as Christianity and Islam (Harper, 2012). Child marriage is often rationalized based on cultural, economic and religious reasons (Amzat and Razum, 2018). This kind of marriage robs young girls of their childhood, education, and future aspirations. It is more often than not supported by social norms, religion, and traditions. It is also mostly a rural phenomenon.

The bad news is that by 2030 , the number of child brides marrying each year would increase

considerably if the current trends continue (UNFPA, 2012). The global goal is to end early marriage and promote the wellbeing adolescent girls. Lemmon and

Box 1: Negative implications of early marriage
$\square$ Large spousal age gaps
$\square$ Limited social support/social capital, due to social isolation
$\square$ Limited educational attainment and no schooling options
$\square$ Low labor participation (low paid labor)
$\square$ Low economic power (high rate of poverty)
$\square$ Low self-esteem and self-determination
$\square$ Intense pressure to become pregnant (high fertility rate)
$\square$ Increased risk of maternal and infant mortality
$\square$ Increased vulnerability to HIV and other Sexually
Transmitted Infections
$\square$ Restricted social mobility/freedom of movement
$\square$ Little access to modern media (TV, radio, newspapers)
$\square$ Lack of skills to be viable to the labor market
High exposure to violence (domestic violence including
marital rape)
Sources: Duflo (2011); UNFPA (2012); and Parsons et al. 2015


ElHarake (2014) observed that ending the tradition of early marriage is more than a moral imperative, as the practice has a lot of negative implications for girls and the community in general. The duo highlighted reduced schooling, limiting girls' economic potential, health implications (high risk of HIV/AIDS, and maternal and infant mortality) among other negative implications of early marriage (see Box 1).

A majority of the girls have to be out of school as a result of early marriage (UNFPA, 2012). Therefore, early marriage translates into a low-level of education among such girls, which also means low labour participation. So, early marriage is one of the factors responsible for the feminization of poverty. With low economic power, it is often difficult for girls to negotiate for any issue within marriage, for instance, safe sex and contraceptive use/family planning, and in general, to contribute to household decision making. There are clear social vulnerabilities that heighten risk for child marriage at national and individual levels. In general, Raj (2009) documented such social vulnerabilities including gender inequity, low level of education and unemployment. Gender inequality is a significant factor responsible for early marriage. The low value placed on women, right from birth, and which persists throughout their lifespan, is a significant factor contributing to early marriage. Parsons et al. (2015: 13) observed that "child-brides often experience overlapping vulnerabilities- they are young, often poor, and undereducated. The vulnerabilities affect the resources and assets they can bring into their marital household, thus reducing their decision-making ability". The crucial fact is that these vulnerabilities affecting half of the population in Nigeria and elsewhere have deleterious effects beyond individuals but also constitute major impediments for national development.

From the preceding background, this study examines the attitudes and behaviours of the community towards adolescent girls' time of marriage with perspectives from faith leaders, community members, and adolescent girls. Few studies have examined the perspective of faith leaders on early marriage. Hence, this study considers the trio (faith leaders, community members, and adolescent girls) in the understanding of early marriage or timing of marriage of adolescent girls. Faith matters in shaping the choices and opportunities available for adolescent girls in northern Nigeria and religious societies in general. The study examined individual and societal behaviour and perceptions that hamper the opportunities of girls, using the strong influence of religion through religious leaders as strong influencers to facilitate this change.

\section{Methods}

This section presents the study design, study area, study population, sample size and procedure, data collection techniques and method of data analysis. The study is a cross-sectional and mixed method study about the attitudes and behaviour of the community towards adolescent girls' time of marriage. It used mixed-methods, quantitative and qualitative. The quantitative aspect enabled representative collection of data to measure community attitude about the 
timing of marriage in the communities of the three local government areas studied. Understanding the choice of early marriage as well as related religious contexts is imperative as a formative ground for the implementation research or policy formulation/implementation. Before the commencement of the study, verbal informed consent of the respondents was obtained, and they were equally accorded the right to opt out when they desired. Confidentiality was assured, and anonymity ensured. There was legitimate community entry with permission obtained from community leaders and parents before data collection.

\section{Study Area and Population}

Three Local Government Areas, Chikun (Mixed Christians and Muslims), Makarfi (Majorly Muslims) and Zangon-Kataf (majorly Christians), were purposively selected for this study. The sampled areas are representative of Nigeria as a multi-religious society. The total population figure for the three areas is 837,837 . The population figures by area are as follows: Chikun: 372 , 272; Makarfi: 146, 574 and Zangon-Kataf: 318,991 (2006 census), making a total of 837,837 . Using online sample calculator, with a confidence level of $95 \%$ and confidence interval of $5 \%$, the sample size for the quantitative survey was 384 individuals. Therefore, a representative sample of 384 community members was selected: 171 from Chikun LGA, 67 from Makarfi and 146 from Zangon-Kataf.

\section{Sample Size and Sampling Technique}

Multistage cluster sampling was used for quantitative aspects. With the use of simple random sampling, four areas were selected from each of the LGAs. In each of the selected areas, streets and compounds were selected randomly in turn, in which questionnaires were systematically administered. Only respondents with at least one married daughter were included in the sample.

The qualitative aspect involved purposive sampling design. While the areas, in general, have some common features, there were some little variations. Therefore, the sampling considered the variations in the selection of the respondents. The variables considered in selecting respondents included age, level of education (both literates and non-literates) and religion. These variables might influence individual understanding of events and life choices. Through the help of the contact persons, community members, recruitment of participants were made through house-house visits to select households with adolescent girls.

In each of the Local Government Areas, the team also conducted eight focus group discussions with adolescent girls (FGDs), and eight in-depth interviews (IDIs) for religious leaders. Faith leaders are religious clerics or preachers with some congregation; and adolescent girls were those within the ages of $12-18$. 


\section{Data collection and Analysis}

The primary data collection involved a between-method triangulation of quantitative and qualitative methods - specifically regarding instruments; questionnaires, IDIs, and FGDs were used. Based on variation in the proportion of Muslims and Christians in the Local Government Areas, 6 Islamic faith leaders and 2 Christian faith leaders were sampled in Makarfi, then 4 for each of the two religious groups in Chikun and, finally, 6 Christians and 2 Islamic faith leaders in Zangon-Kataf. A total of 24 IDIs were conducted.

The FDGs were conducted among adolescent girls, with 6-8 girls per session. The variables of religion, education, and marital status were considered in the selection of the girls to ensure the homogeneity of each group, and to ensure that various groups were included in the sample. Invariably, literate and non-literate girls and married and unmarried were sampled. The ring form of sitting arrangement was maintained during the discussion: 6 sessions for Muslim girls and two sessions for Christian girls were conducted in Makarfi, then 4 for each of the two religious groups in Chikun and, finally, six sessions for Christian girls and two sessions for Muslim girls in ZangonKataf.

The questionnaire, apart from the section on the demographic characteristics, was sectionalized based on the objectives of the study, to collect information on the timing of marriage among adolescent girls. All 384 questionnaires were administered in the form of personal interviews. This method enabled the research assistants to ask questions and tick/record respondents' responses. The method of questionnaire administration ensured a complete return rate of $100 \%$ and accurate responses.

Quantitative data analysis was performed with the use of relevant statistical tools - both descriptive and inferential statistics were deployed. Quantitative data analysis was by SPSS software, and chi-square test of proportion for statistical significance of association was performed to understand the influence of specific religious contexts. Statistical confidence level was set at $95 \%$. The qualitative data generated through FGDs, and IDIs and analysed with the use of content analysis and ethnography following steps in framework analysis (see Lacey \& Luff, 2001: 3-4).

\section{Findings}

This section covers the socio-demographic profile of respondents and the specific objectives of the study.

\section{Socio-demographic Characteristics of the Respondents}

The questionnaires were returned $100 \%$. Only respondents with at least one married daughter were eligible for this quantitative aspect. Therefore, up to $70 \%$ of the respondents were aged 41 and above. It is however not surprising that there were a few respondents $(3.9 \%)$ within the age bracket of 18-30. In the qualitative method, there was a story of a girl who married at 10 , and had given birth and divorced three times. If early marriage remains a cycle, it is 
possible to have grandchildren at 30 . There were more women among the respondents (54.4\%) compared to men (45.6\%). More importantly, all the major ethnic groups in the areas were represented including Hausa (35.2\%), Bajju (13.3), Gbagi (12.8) and Kataf (11.5) among others. In general, the study areas are multi-ethnic and multi-religious environments (see Table 2).

Additional socio-demographic characteristics examined include education, occupation and marital status (see Table 1). Of the respondents, $15.6 \%$ had no formal education while those with Biblical and Quranic education only were $2.3 \%$ and $18.8 \%$ respectively. Those with primary education only were $22.1 \%$, with secondary education was $25.5 \%$ and with postsecondary education was $15.6 \%$. The respondents who were fairly educated were from the urban area of Chikun, while the majority of those without any formal education and with Quranic education only were from Makarfi, a rural and Muslim-dominated area. On the marital status of the respondents, $87.5 \%$ were married. Only a few were single $(1 \%)$, divorced $(0.5 \%)$, separated $(0.3 \%)$ and widow(er)s $(10.7 \%)$. On the study areas, a majority of the respondents were predominantly farmers (39.3\%), and another substantive majority were artisans (27.1\%). Those in menial jobs, unemployed and civil servants constituted about $10 \%$ each.

Table 1: Socio-demographic Characteristics of the Respondents I

\begin{tabular}{|llll} 
Characteristics & Response & Frequency & Percent \\
\hline Highest level of & No formal education & 60 & 15.6 \\
& Biblical education only & 9 & 2.3 \\
& Quranic education only & 72 & 18.8 \\
& Primary education & 85 & 22.1 \\
& Secondary education & 98 & 25.5 \\
& Post-secondary education & 60 & 15.6 \\
\hline Marital status & Total & $\mathbf{3 8 4}$ & $\mathbf{1 0 0 . 0}$ \\
& Single (never married) & 4 & 1.0 \\
& Married & 336 & 87.5 \\
& Divorced & 2 & .5 \\
& Separated & 1 & .3 \\
& Widow(er) & 41 & 10.7 \\
\cline { 2 - 4 } Occupation & Total & $\mathbf{3 8 4}$ & $\mathbf{1 0 0 . 0}$ \\
& Unemployed & 39 & 10.2 \\
& Studying & 8 & 2.1 \\
& Civil service & 38 & 9.9 \\
& Professional & 6 & 1.6 \\
& Farming & 151 & 39.3 \\
& Artisanship & 104 & 27.1 \\
& Menial work & 38 & 9.9 \\
& Total & $\mathbf{3 8 4}$ & $\mathbf{1 0 0 . 0}$
\end{tabular}


On the religious composition of the study area, Christians constituted $65.6 \%$, while Muslims were 33.6\% (See Table 2). A higher number of questionnaires was administered in the Christian dominated area of Zango-Kataf while the Muslim-dominated area of Makarfi had fewer questionnaires (percentage derived based on the population of the areas). Religiosity is a significant feature of Nigerian societies. Apart from people identifying with certain religions, they also attend religious gatherings from time to time. Almost three out of 10 respondents claimed that they often attended religious congregations on a daily basis. Generally, the majority of the respondents (99\%) claimed to be very regular in religious gatherings.

In all, $61.2 \%$ of the respondents affirmed to have listened to early marriage discussions in their respective religious gatherings. Others had attended gatherings in the clinic (1.6\%) or within the community $(17.7 \%)$. At least, more than $90 \%$ of the respondents had at one point in time listened to discussions on the timing of marriage for adolescent girls. The religious gathering seemed to be a common place where such issue had been previously discussed. The last issue in Table 2 is about daughters who have married and their age of marriage. In all, $35.2 \%$ reported at least one to three daughters who married before 18 .

Table 2: Socio-demographic Characteristics of the Respondents II

\begin{tabular}{|l|lrr} 
Characteristics & Response & Frequency & Percent \\
Religion & Christianity & 252 & 65.6 \\
& Islam & 129 & 33.6 \\
& Others & 3 & .8 \\
& Total & $\mathbf{3 8 4}$ & $\mathbf{1 0 0 . 0}$ \\
Attendance at religious & Daily (every day of the & 112 & 29.2 \\
congregation/gathering & month) & 126 & 32.8 \\
& Most days (more than 4/5 & & \\
& days per month but not & & \\
& every day) & 120 & 31.3 \\
& Weekly & 22 & 5.7 \\
& Monthly & 4 & 1.0 \\
& Never & $\mathbf{3 8 4}$ & $\mathbf{1 0 0 . 0}$ \\
& Total & 68 & 17.7 \\
Ever been in a gathering where & Yes, in a community & & \\
issues of time of marriage for girls & gathering & 6 & 1.6 \\
was discussed & Yes, in a community & & \\
& clinic & 235 & 61.2 \\
& Yes, in religious & & \\
& gatherings & 20 & 5.2 \\
& Yes, in others & 16 & 4.2 \\
& Yes, in both community & & \\
& and religious gatherings & 1 & .3 \\
& Yes, in all mentioned & 38 & 9.9 \\
\hline gatherings & $\mathbf{3 8 4}$ & $\mathbf{1 0 0 . 0}$ \\
Number of daughters married & No & 63 & 18.8 \\
before the age of 18 & Total & 16.4
\end{tabular}


Table 3: Religion and number of daughters married before 18 and beneficial to marry later

\begin{tabular}{|c|c|c|c|c|c|}
\hline & \multicolumn{3}{|c|}{ Number of daughters married before 18} & \multirow[t]{2}{*}{ Total } \\
\hline & & $\begin{array}{l}1 \text { before } 18 \\
\text { years }\end{array}$ & $\begin{array}{l}2 \text { or } 3 \text { before } \\
18 \text { years }\end{array}$ & $\begin{array}{l}\text { All married above } \\
18 \text { years }\end{array}$ & \\
\hline \multirow[t]{3}{*}{ Religion } & Christianity & 31 & 29 & 192 & $252(65.6 \%)$ \\
\hline & Islam & 40 & 34 & 55 & $129(33.6 \%)$ \\
\hline & Others & 1 & 0 & 2 & $3(0.8 \%)$ \\
\hline \multicolumn{2}{|r|}{ Total } & $72(18.8 \%)$ & $63(16.4 \%)$ & $249(64.8 \%)$ & $384(100 \%)$ \\
\hline \multicolumn{6}{|c|}{ Chi-square computed value =43.046, Critical value=9.488, df=4, $\alpha @ 0.05$} \\
\hline \multicolumn{6}{|c|}{ Religion and whether it is beneficial to marry later than 18} \\
\hline & & \multicolumn{3}{|c|}{ Beneficial to marry later than at 18} & Total \\
\hline & & Yes & No & \begin{tabular}{l|l} 
I don't know \\
\end{tabular} & \\
\hline \multirow[t]{3}{*}{ Religion } & Christianity & 218 & 27 & 7 & $252(65.6 \%)$ \\
\hline & Islam & 97 & 23 & 9 & $129(33.6 \%)$ \\
\hline & Others & 2 & 1 & 0 & $3(0.8 \%)$ \\
\hline & Total & $317(82.5 \%$ & \begin{tabular}{l|l} 
& $51(13.3 \%$ \\
\end{tabular} & \begin{tabular}{l|l|}
) & $16(4.2 \%)$ \\
\end{tabular} & $384(\mathbf{1 0 0} \%)$ \\
\hline \multicolumn{6}{|c|}{ Chi-square computed value $=9.320$, Critical value $=9.488, \mathrm{df}=4, \alpha @ 0.05$} \\
\hline
\end{tabular}

Table 3 shows that religion is significantly associated with whether a daughter marries before the age of 18 or not. While $23.8 \%$ of Christians surveyed practiced early marriage, the percentage goes up to $57.3 \%$ among the Muslim respondents ${ }^{1}$. Thus, the significant number of child marriage happens in the Muslim region. There is no difference between Christians and Muslims on the facts that marriage at a later age than 18 is beneficial (see Table 3 ).

\section{Attitudes and Behaviours of Congregations/Communities}

From Table 5, 35.2\% of the respondents had one or more daughters married before the age of 18 , but when asked when a girl-child should get married, only $17.2 \%$ mentioned age below 18 (see Table 4 ). The remaining $82.8 \%$ cited ages above 18. This shows that behaviours do not always follow attitudes or opinions (17.2\% believe in early marriage yet more families than that, a $35.2 \%$, married their daughters early). Therefore, actual theoretical knowledge on an issue might not always lead to positive correspondent practice. These results also signify a high level of theoretical knowledge of when a girl should be married, $82.8 \%$, even though a substantive majority (59.6\%) did not know the legal age of marriage in Nigeria. Only 37\% affirmed that it is 18 years and above while 3.4\% mentioned ages below 18 and 59.6\% claimed that "they don't know." The implication is glaring: many would flaunt the law because of ignorance (which is not an excuse to break the law). For a majority, it could be

1 Note the margin of error moves to \pm 10 since the samples are smaller for Christians (252) and Muslims (129). 
assumed as usual to marry below the age of 18 since there is no knowledge of any legal provision against such action. Therefore, marrying a girl below the age of 18 might not be perceived as a crime but as a cultural prescription.

The qualitative provided further insights. The primary yardstick to determine early marriage is the age at marriage. During the FGDs among adolescent girls, most girls from the Muslim majority Makarfi area had married between 12 and 16 but would love to have been married later as many of them thought of 16-18 as the approximate ideal age of marriage. In Christianity dominated areas, many of the girls mentioned 20-21 as the ideal age to marry, although a few of them also married earlier. The issue is that some communities have been fond of early marriage and therefore did not understand the importance of delayed marriage. For instance, a girl (19 years old) who have been married three times participated in one FGD session. Another participant, who was married at 12 and was then 15, who lost a set of twins, she was very active in explaining the adverse effects of early marriage. She observed that:

There are several implications of early marriage, and they include vulnerability to diseases, divorce, and poverty. So many girls confronting challenges in their marital home is because they never take their time before getting married.

An adolescent Muslim discussant observed that:

We marry early in their village because we do not attend any school [western or Islamic] or engage in any craft. So when our parents decide it is time for marriage, we usually comply.

A Christian discussant observed that:

A girl child should get married at the age of 25 years. This is because at that age she would have completed her education and also possibly gotten a job that could sustain her in her marital home.

According to qualitative accounts, Muslim majority areas, e.g., Makarfi, are those with the most permissive context for early marriage. Not all faith leaders are clear about the right "age" of marriage (18). It is generally said that a girl can marry when she is "mature," which is generally related to starting the menstruation, not to her age or school level. The equation of mensuration to maturity was observed during the qualitative survey in Muslim-dominated communities.

A Muslim faith leader observed that:

The foundation of marriage is an agreement between the partners.

If it is possible, the marriage items such as dowry shall not be much. For me, marriage is done when a girl is matured and gets a partner who shall pay the dowry. The parent of the bride will tell the amount of the money to be paid as bride price. You know 
the village situation, even when a girl has a partner her marriage will be delayed until she reaches 14 years. Yes! I am of the view that, early marriage less than 14 years should be stopped, and delayed to at least 14 years.

In general, up to $82.6 \%$ revealed that there are accruing benefits to marrying later. An overwhelming majority (96.4\%) agreed that a girl should get some education before venturing to marriage. Education, in this regard, means at least basic education, which could be obtained up to 18 years of age. Functional education means a completed secondary education or some level of postsecondary education. The implication of obtaining some basic education means delayed marriage, which perhaps many of the respondents did not envisage.

In the Christian majority Kataf and the mixed Chikun areas, the majority of the faith leaders observed in the in-depth interviews that early marriage is a major problem in the societies where they are prevalent. Some of them cited some of the major problems linked to early marriage including poverty, sexual diseases and inadequate education for the girl-children. In general, there is no specific age of marriage, but people rush for marriage as a result of the need for material things. They specifically said that a girl should be matured before marriage to be able to know her left from her right. Most results interviews observed that there is generally no specific age for marriage in the communities. The timing of marriage is usually at the discretion of the parents who possibly could have been influenced by certain religious precepts. The Christian faith leaders reported that early marriage is not particularly encouraged in Christianity, but there are cases of early marriages due to the inability of many adherents to follow religious tenets because they become pregnant (out of wedlock), then have to get married. A Christian interviewee observed that "early marriage is a tradition, not religious rule. The reason why it is a tradition is that girls do not follow the right channel which is the Christian way of marriage but follow the traditional means which is by getting pregnant for someone at an early age and they do that because of material gains". In general, he cited the Holy Bible, which says, "marriage is honorable" (Hebrew, 13: 14) and a religious event. On the other hand, marriage is also viewed as a tradition of Islam and a religious event.

Religion plays a significant role, but it depends on the teaching and doctrines of every church and religion. In Christianity, the bible says a girl should marry when she is matured... that there should not be a specific age for marriage but the person should be mature spiritually, financially and other aspects. (IDI, Zangon-Kataf, Christian faith leader) 
Table 4: Behaviour of Congregations/Communities

\begin{tabular}{|c|c|c|c|}
\hline Issues/Questions & Response & Frequency & Percent \\
\hline \multirow{3}{*}{$\begin{array}{l}\text { At what age do you think a female } \\
\text { child should get married? }\end{array}$} & Less than 18 years & 66 & 17.2 \\
\hline & 18 years and above & 318 & 82.8 \\
\hline & Total & 384 & 100.0 \\
\hline \multirow{4}{*}{$\begin{array}{l}\text { Could you tell us what the minimum } \\
\text { official/legal age of marriage is in } \\
\text { Nigeria? }\end{array}$} & Below 18 years & 13 & 3.4 \\
\hline & 18 years and above & 142 & 37.0 \\
\hline & I don't know & 229 & 59.6 \\
\hline & Total & 384 & 100.0 \\
\hline \multirow{4}{*}{$\begin{array}{l}\text { Do you think there are benefits to } \\
\text { marrying later than at } 18 ?\end{array}$} & Yes & 317 & 82.6 \\
\hline & No & 51 & 13.3 \\
\hline & I don't know & 16 & 4.2 \\
\hline & Total & 384 & 100.0 \\
\hline \multirow{3}{*}{$\begin{array}{l}\text { Do you believe in girl-child education } \\
\text { then marry later? }\end{array}$} & Yes & 370 & 96.4 \\
\hline & No & 14 & 3.6 \\
\hline & Total & 384 & 100.0 \\
\hline \multirow{3}{*}{$\begin{array}{l}\text { Focus of women only in the kitchen and } \\
\text { on domestic work }\end{array}$} & Yes & 43 & 11.2 \\
\hline & No & 341 & 88.8 \\
\hline & Total & 384 & 100.0 \\
\hline \multirow[t]{8}{*}{$\begin{array}{l}\text { Condition/s a daughter could be given } \\
\text { out [marry] before the age of } 18\end{array}$} & $\begin{array}{l}\text { Unintended } \\
\text { pregnancy }\end{array}$ & 126 & 32.8 \\
\hline & $\begin{array}{l}\text { Sexual } \\
\text { waywardness }\end{array}$ & 115 & 29.9 \\
\hline & $\begin{array}{l}\text { With her desire to } \\
\text { marry }\end{array}$ & 70 & 18.2 \\
\hline & Never at all & 37 & 9.6 \\
\hline & $\begin{array}{l}\text { Not academically } \\
\text { good }\end{array}$ & 8 & 2.1 \\
\hline & Religious advice & 27 & 7.0 \\
\hline & Others specify & 1 & .3 \\
\hline & Total & 384 & 100.0 \\
\hline
\end{tabular}

The gender belief that often encourages early marriage is that women should generally remain in the private realm, mostly without paid employment. The implication is that the domestic realm (including child care and housework) should be the main priority for women. Following from the finding that a majority of the respondents believe in education-then marriage, it is not surprising that a majority $(88.8 \%)$ also agreed that women should not solely be confined to the kitchen. There was still some minority (11.2\%) who recommended that women should be confined to the kitchen. This category of a minority would favour early marriage.

The qualitative data showed that there are some fundamental fears of parents who opt for early marriage. In religious circles, the fear of pre-marital sexual intercourse is one reason why some opt for early marriage. Among the respondents, $29.9 \%$ mentioned sexual waywardness as a factor for early marriage. The idea is that it could be better to marry if a person cannot abstain from sexual intercourse. The fear of unwanted pregnancy, which is still a taboo, precipitates such fear. Once a girl is pregnant, it (most times) means marriage. 
A Christian faith leader averred that: "Here the tradition demands that when pregnant out of wedlock, the girl must give birth in her boyfriend's place." This is why unwanted pregnancy $(32.8 \%)$ tops the list of conditions that would warrant early marriage. In the Christian majority Zango-Kataf region, during the FDGs and IDIs, there is a general belief that a girl that is pregnant should be married off. In the Muslim majority Markarfi region, it is a cultural aberration for a lady to be pregnant before marriage. It would induce severe lifetime social stigma for both the intending mother and the unborn child.

Also, respondents highlighted other conditions that could warrant a girl to marry before the age of 18 . Some respondents $(2.1 \%)$ stated that if a girl could be married off if she is not good in her education. Another set $(18.2 \%)$ thought that her desire to get married should be the main reason while $7 \%$ of the respondents though religious advice could prompt a girl to be married early. Only $9.6 \%$ of the respondents would never marry off an underage irrespective of the conditions as mentioned earlier.

Among Muslim communities, Iyaka was a concept that came up during some focus group discussions. The respondents equated marriage to iyaka, i.e., - "when it is your time to marry, it is just like death, it could come whether one wants it or not." This (iyaka) signifies a kind of powerlessness for girls. Therefore marriage was something that happens, and if a girl rejects, she is beaten until she agrees. The beating could involve inflicting of fracture on the hand or leg. A Muslim discussant in Makarfi observed that:

Sometimes the male relatives in the family will tell you that they will beat you, better to break your bones and send you to a bonesetter than for you not to marry when they want.

\section{Box 2: Good Practice on Age of Early Marriage}

For a Christian community in the Muslim majority Makarfi area, the church is playing a significant role as an agent of social control, through the preaching as well as through the testing of genotype, HIV/AIDs and pregnancy for the girls before they are allowed to marry. The community itself seems to have adopted 18 years as the age limit for a girl to be married, except when there is a case of an unexpected pregnancy.
The discussant in a particular session mentioned a girl who was tortured to the point of a fracture thereby forcing her to consent to marriage. The implication is that the girls forcefully consented to most of the marriages. Most of the girls were not attending any school (both conventional and Islamic). "The girls did not have a say in when they wanted to marry, even while in an Islamic school, they were not allowed to finish because their father felt they were matured enough to marry." There appears to be a contradiction with the perceptions of the girls on their ability to get control of when they would want to marry because almost all of them asserted that they would want to attain more education. However, even those girls who were already in a primary school, as well as an Islamic school, were not allowed to complete their education before they were married off. Most of 
the respondents suggested that they tend to marry early in their village because they were not schooling (western or Islamic) or engaged in any craft that their parents decide that it time to marry.

Most Muslims girls marry when their parents think that it is time for the girl to get married regardless of their interest. Filial obedience was the main reason why most of the respondents married. Even though when some of the participants wanted to continue schooling their parents felt it was time for them to get married since they did not have the money to help them continue with their schooling.

\section{Discussion}

This study has demonstrated that religion is a significant justification for the practice of early marriage. The Islamic context provides permissive justification for early marriage (source?). Therefore, more Muslims in the study favoured early marriage. Lemmon and ElHarake (2014: 16), however, observed that there is "no single religion associated with the practice across countries; various religions had high rates of child marriage, depending on the country." A report found that religion is an essential factor in Chad, Nigeria, Cameroon, Burkina Faso, Malawi, Ethiopia, India, and Bangladesh (ICRW, 2007). For instance, Orthodox Christians (about 82.5\%) dominates the Amhara region of Ethiopia while Muslims are around $17.2 \%$. The rate of early marriage in Amhara was 50\% (Pathfinder International, 2006). Islamic communities in Burkina Faso also have high rates of early marriage (Gemignani and Wodon, 2015b). While the general conclusion is that early marriage is higher among Muslims because it is very high in Muslim dominated communities (especially in northern Nigeria), there is no definite data on early marriage per religion. This study, however, conforms to the general conclusion as early marriage was more prevalent in the Muslim-dominated area of Makarfi.

The Muslim-dominated rural area of Makarfi presented some favourable attitude towards early marriage. In Zangon-Kataf and Chikun, the majority of the faith leaders in their interviews observed that early marriage was a significant problem in their communities and could identify some adverse effects. The date revealed that the timing of marriage is usually at the discretion of the parents who possibly could have been influenced by certain religious precepts. According to interviews with faith leaders, early marriage is not particularly encouraged in Christianity, but there are cases of early marriages, which were due to pregnancy out of wedlock. In the Christian communities, early marriage, where it occurs, is viewed as a tradition, not a religious rule.

Lemmon and ElHarake (2014) observed a mix of complex factors that are responsible for the practice, and such factors also slow down the pace of eliminating child marriage. "Culture and tradition push to maintain the status quo, and the twin perils of poverty and lack of education also drive the practice" Lemmon and ElHarake (2014: 4). Despite efforts to improve educational opportunities and alleviate poverty, in religious societies with 
deep-rooted cultural practices, it is important to shift the traditional justification for early marriage especially through a constant push to shift social norms. The implication is that the cultural determinants, peak of which is "religious belief," that are reinforcing the practice must be addressed. The study also found that urban Muslims in Chikun hold a different perspective regarding early marriage.

The critical issue is not just a matter of one particular religion; it also involves religious and cultural notions of the roles of women in the community. The religious division of labour based on gender constructions of roles is a major channel through which religion influences the timing of marriage. When girls are identified with their future roles as mothers and wives and not as providers and leaders in the home or community, they tend to follow different education and labour lines, which make them marry early (Gemignani and Wodon, 2015a, 2015b). These labour and educational lines typify low interest in education in general or higher education, and low interest in labour participation. This assertion about cultural constructions of roles is essential to the extent that two communities with similar religious practices might have differential rates of early marriage. Such construction might also be influenced by location (rural-urban dichotomy) (Gemignani and Wodon, 2015).

Some of the respondents in the study recognized that early marriage makes adolescent to be vulnerable to many conditions. It has been observed that dependency on the male partner is a significant basis of exposure to violence, including psychological, emotional, physical and sexual violence. It is not uncommon to view married women as property of their spouse. Such view gives room for undue manipulation and infractions on women's rights (and human rights in general). The financial transaction involved in marriage is sometimes interpreted as a transfer of ownership of the female body to the spouse. Such an interpretation makes it difficult to report or prosecute marital rape in most African countries. It is also the norm to chastise women through withdrawal of material resources (including monetary allowances and food). This is because a majority of child brides have minimal access to personal income and social capital (Duflo, 2011). Throughout the lifespan of a child bride (even after becoming an adult), her earning potentials have been (heinously) jeopardized. Therefore, the death of her spouse is an automatic cessation of her means of livelihood. A majority of them must "rush" into another marriage as a livelihood strategy. Factors such as a large spousal gap and a precipitated remarriage explain vulnerability to HIV/AIDS and domestic violence (although not covered in this study). Many child brides must stay in a marriage at all costs including enduring severe abuses because their livelihood depends on marriage.

\section{Conclusion}

From the discussion and evidence so far, a substantial majority of the respondents had at one point in time listened to the discussion on the timing of marriage for adolescent girls. The religious gathering seemed to be a common 
place where such issues are discussed. Early marriage is also prevalent in the study areas. There is a high level of theoretical knowledge of when a girl should be married even though a substantial majority did not know the legal age of marriage in Nigeria. The implication is glaring: many would flaunt the law because of acclaimed ignorance or because it contradicts their religious stance.

Furthermore, there are some fundamental fears of parents who opt for early marriage. In religious circles, the fear of pre-marital sexual intercourse and eventual pregnancy constitute the main reasons why some opt for early marriage. Filial obedience is the primary reason why girls are married early, which is mostly against their wish. The study observed powerlessness on the part of the girls to influence their timing of marriage in rural communities. In some instances, there is violence against them if they disagree to marry. Due to fear of premarital pregnancy, there need to incorporate sex education in the school curriculum and allay the fears of parents about it.

The general submission is that the faith leaders have many roles to play in communicating to their congregations on the timing of marriage for girls. The critical question is whether they are doing enough to warrant a change in attitude and behaviour in their communities. Since community members, especially parents, are implicated in early marriage for adolescent girls, it is crucial that community conversations led by faith leaders be instituted involving parents, guardians and traditional rulers/institutions. More importantly, faith leaders are important grassroots mobilizers. It is, therefore, a matter of harnessing available potentials to address early marriage in their respective communities.

\section{References}

African Development Information, Nigeria Data Map - Child 'Marriage'-36 State \& Abuja http://www.afri-dev.info/.

Amzat and Razum, O. (2018) Towards a Sociology of Health Discourse in Africa. Dordrecht: Springer International Publishing.

Christian Aid (2017) Religion and the Adolescent Girl: A formative study in Kaduna state. Abuja: Christian Aid.

Duflo, E. (2011) Women's Empowerment and Economic Development. Cambridge: National Bureau of Economic Research.

Gemignani, R. and Wodon, Q. (2015a) Child Marriage and Faith Affiliation in Sub-Saharan Africa: Stylized Facts and Heterogeneity. The Review of Faith \& International Affairs, 13(3): 41-47, DOI: 10.1080/15570274.2015. 1075752.

Gemignani, R. and Wodon, Q. (2015b) "Child Marriage in Burkina Faso: A Comparison across Three Communities." In Child Marriage and Education in Sub-Saharan Africa, edited by Q. Wodon. Washington, DC: World Bank Study, World Bank. 
Harper, J. (2012) 84 percent of the world population has faith; a third are Christian. The Washington Times - December 23, 2012. https://www.washingtontimes.com/blog/watercooler/2012/dec/23/84-percent-worldpopulation-has-faith-third-are-ch/. Accessed on February 3, 2018.

International Center for Research on Women [ICRW] (2007) New Insights on Preventing Child Marriage: A Global Analysis of Factors and Programs. International Center for Research on Women.

Lacey, A. and Luff, D. (2001) Trent Focus for Research and Development in Primary Health Care: Qualitative Data Analysis. Trent Focus Group.

Lemmon, G.T. and ElHarake, L.S. (2014) Child Brides, Global Consequences: How to End Child Marriage. NY: The Council on Foreign Relations (CFR).

National Population Commission (NPC) [Nigeria] and ICF Macro (2009) Nigeria Demographic and Health Survey 2008. Abuja, Nigeria: National Population Commission and ICF Macro.

NBS, UNICEF and UNFPA (2013) Nigeria: Multiple Indicator Cluster Survey 2011. Abuja: Nigeria.

Parsons, J., Edmeades, J., Kes, A., Petroni, S., Sexton, M. and Wodon, Q. (2015) Economic Impacts of Child Marriage: A Review of the Literature. The Review of Faith \& International Affairs, 13(3): 12-22, DOI: 10.1080/15570274.2015.1075757.

Pathfinder International (2006) Ethiopia: Creating partnership to prevent early marriage in the Ahmara region. Addis Ababa: Pathfinder International.

Raj, A. (2009) When the mother is a child: the impact of child marriage on the health and human rights of girls. Archive of Diseases of Childhood, 95(11).

United Nations Population Fund [UNFPA] (2012) Marrying too young: End child marriage. New York: UNFPA.

Walker, J.A. (2015) Engaging Islamic Opinion Leaders on Child Marriage: Preliminary Results from Pilot Projects in Nigeria. The Review of Faith \& International Affairs, 13(3): 48-58. 